\title{
Temperature Parameterization of the Stabilizer Consumption in Naturally and Artificially Aged Single Base Gunpowder
}

\author{
Ljiljana Jelisavac ${ }^{1)}$ \\ Slaviša Stojiljković ${ }^{2)}$ \\ Siniša Gaćic ${ }^{3)}$ \\ Aleksandar Milojković ${ }^{1)}$ \\ Jelena Petković Cvetković ${ }^{1)}$
}

\begin{abstract}
The most reliable way of chemical stability assessment and the lifetime prediction of nitrocellulose (NC) gunpowder (GP) by measuring of the stabilizer contents is to monitor the consumption of the stabilizer with time, under storage conditions. Due to the limited time available for testing of reliable lifetime prediction the various methods based on the artificially aging process (which simulates the natural aging of GP) has been developed. The aim is to reach equivalent aging in much shorter time then at ambient temperature under naturally storage conditions.

The present article describes the results of comparative analysis of the lifetime prediction of naturally and artificially aged different series of $\mathrm{NC}-40$ powder at ambient temperature $25^{\circ} \mathrm{C}$.

It is showed that empirical value of activation energy of $80 \mathrm{~kJ} / \mathrm{mol}$ can be used for extrapolation of the reaction rate constant of the stabilizer consumption in the naturally aged $\mathrm{NC}-40$ powder from average annual temperature $15^{\circ} \mathrm{C}$ in $\mathrm{KB}-1 \mathrm{collection}$ (conditions of continental climate) to an ambient temperature of $25^{\circ} \mathrm{C}$. The lifetime of naturally aged $\mathrm{NC}-40$ powder calculated in this way is in accordance with the lifetime of artificially aged GPs calculated at ambient temperature $25^{\circ} \mathrm{C}$, according to worldwide used standard AOP-48 Ed. 2 . The lifetime of the naturally aged NC-40 powder calculated in this way is in accordance with the lifetime which was calculated by Van't Hoff extrapolation method, too.
\end{abstract}

Key words: gunpowder, single base gunpowder, chemical stability, storage safety, stabilizers, natural aging, artificial aging, lifetime prediction.

\section{Introduction}

$\mathrm{N}$ ATIONAL standard SORS 8069/91 prescribes procedure of the assessment of chemical stability of nitrocellulose (NC) gunpowder (GP) by periodical measuring of the remained stabilizer contents in natural aged GP in storage condition [1]. Periodically examinations of chemical stability of different type of single base GP in laboratory of TRZ Kragujevac, by measuring of stabilizer contents, were carried out. Analysis of results of GP chemical stability control, has shown that the measured values of remained stabilizer in single base NC types of GP, after about twenty years of storage in powder collection with continental climate conditions (KB-1), were at expected level.

However, in literature there were results of periodically control, that indicated a rapid decreasing of chemical stability of some series of NC-40 powders, storaged in collection KB-2 in conditions of mediteranean climate and delaborated from ammunition [2,3]. According to that the aim of this examiation was prediction of storage lifetime (lifetime) of different series of single base type NC-40 which were storaged in KB-1 colection of powders. In this article, the results of periodical measuring of stabilizer content with time in GP under conditions of continental climate in Kragujevac is used for lifetime prediction of single base NC-40 powders.
The results of systematic temperature monitoring in ammunition depot showed that the average annual temperature in the M-40 type warehouses in the continental part of the country is $15^{\circ} \mathrm{C}[4,5]$.Therefore, in the calculations, as the average annual temperature in powder collection, KB1 , with continental climate, a temperature of $15^{\circ} \mathrm{C}$ was used [2-5].

By the mathematical description (exponential kinetic model) of the results of the periodic measurements of the stabilizer contents with time (in years) under storage conditions $\left(T_{K B-1}=15^{\circ} \mathrm{C}\right)$, it is possible to determine the constants of the rate of reaction of the stabilizer consumption in $\mathrm{KB}-1$ at the storage temperature, $k_{15}{ }^{\circ} \mathrm{C}[1,5]$.

Nowadays, standard AOP-48 Ed.2 for the lifetime prediction of powder and propellant at ambient temperature $25^{\circ} \mathrm{C}$ is very actual [6]. Standard prescribes accelerated aging of GP by heating of sample at multi-temperatures. The experimental results of the periodic determination of the stabilizers content in accelerated aged of GP are mathematically described by application of the $\mathrm{n}^{\text {th }}$ order kinetic model. Arrhenius expression is using for the temperature parameterization of the stabilizer consumption from the test temperature to an ambient temperature of $25^{\circ} \mathrm{C}$.

\footnotetext{
Military Technical Institute (VTI), Ratka Resanovića 1, 11132 Belgrade, SERBIA

TRZ Đorđe Dimitrijević Đura, 34000 Kragujevac, SERBIA

3) Technical Testing Centre, Vojvode Stepe 445, 11000 Belgrade, SERBIA

Correspondence to: Ljiljana Jelisavac; e-mail: jelisavach@yahoo.com
} 
In order to compare the lifetime values of the accelerated aged of GP at $25^{\circ} \mathrm{C}$ and the lifetime values of naturally aged of $\mathrm{GP}$ at the storage temperature $\left(15^{\circ} \mathrm{C}\right)$, it is necessary to take into the considerations the constant of the reaction rate of the stabilizer consumption at these two temperatures. The lifetime values were calculated according to standard AOP-48 Ed. 2 and the constant of the reaction rate of the stabilizer consumption was extrapolated from the storage temperature $T_{K B-1}=15^{\circ} \mathrm{C}$ to the ambient temperature of $25^{\circ} \mathrm{C}$.

In literature, extrapolation of the constant of the stabilizer consumption in $\mathrm{NC}$ powders from the storage temperature of $15^{\circ} \mathrm{C}$ to ambient temperature using the Arrhenius expression and value of $E a=122 \mathrm{~kJ} / \mathrm{mol}$, is described. Authors used activation energy from literature, which was obtained for the same type of powder as examined gunpowder in article [5].

1. In this paper, focus is on the application of different types procedures of temperature parameterization of the chemical reaction rate from storage temperature $15^{\circ} \mathrm{C}$ to ambient temperature,

1. Arrhenius expression with values of:

- empirical activation energies $E a=80 \mathrm{~kJ} / \mathrm{mol}$ or $E a=120 \mathrm{~kJ} / \mathrm{mol}[6,7]$ and

- experimentally determined activation energy $E a$ by application of the $n^{\text {th }}$ order kinetic model for GP sample of the same type as examined [3,6,8-10].

2. Vant Hoff's extrapolation procedure [3,10,11].

In the domestic literature there is data about extrapolation from the storage temperature to a temperature of $25^{\circ} \mathrm{C}$ using the literature experimental value $E a=122 \mathrm{~kJ} / \mathrm{mol}$. In this work, experimental value of $E a$ experimentally obtained for same type of powder according to AOP-48 Ed.2 will be used.

In our country, the results of the research in which the extrapolation from the storage temperature to an ambient temperature $25^{\circ} \mathrm{C}$ was performed, using empirical $E a=80 \mathrm{~kJ} / \mathrm{mol}$ were not published.

By extrapolation of already existing results of stabilizer consumption, obtained in conditions of natural ageing and therefore represent real values, to the ambient temperature $25^{\circ} \mathrm{C}$, it is made possible to compare them with the results obtained by accelerated ageing in much shorter period of time. In that way an insight is provided in dynamics of ageing of examined gunpowders, considering that some series have shown fast decrease of stability.

Aim of this examination is comparison of the life time of different series of NC-40 gunpowder at ambient temperature $25^{\circ} \mathrm{C}$ :

- three series of $\mathrm{NC}-40$ which were naturally aged in storage KB-1 under continental climate conditions at temperature $15^{\circ} \mathrm{C}$ and

- one series of $\mathrm{NC}-40$ gunpowder which was artificially aged by multi-temperature heating at $65^{\circ} \mathrm{C}, 70{ }^{\circ} \mathrm{C}, 80^{\circ} \mathrm{C}$ and $90^{\circ} \mathrm{C}$ according to worldwide used standard AOP-48 Ed.2.

\section{Theoretical part}

Single-base nitrocellulose GP is based on the nitro-esters which undergo slow thermal decomposition even at ambient temperature. The products of degradation can cause a reduction of chemical stability of GP and lead to self-ignition due to the exothermic nature of reactions involved. The GP are the most frequently stabilized with diphenylamine (DPA), and chemically bind the evolved gases and remove them from the matrix $[2,3,10]$. The monitoring of the stabilizer consumption over a time-temperature conditions permits the estimation of lifetime of GP. There are several different approaches, which involve the accelerated ageing of GP samples at various temperatures.

The results of periodical measuring of the stabilizer contents in different temperature - time conditions can be mathematically described by kinetic modelling using different kinetic expressions for rate of reaction of stabilizer consumptions.

According to actual standard AOP-48 Ed.2, for prediction of the lifetime of artificially aged GP, experimental results of stabilizer consumption can be described using expression for rate of reaction of the $\mathrm{n}^{\text {th }}$ order $[6,8-10,12,13]$.

$$
\left(\frac{d C s(t)}{d t}\right)_{T}=k^{\prime}(T) C_{S}(t, T)^{n}
$$

By separating variables and integrating, an expression is obtained, which is used to describe the experimental data of the stabilizer consumption.

$$
\begin{gathered}
C_{S}(t, T)=C_{S}(0)[1-(1-n) k(T) t]^{(1 / 1-n)} \\
k(T)=\frac{k^{\prime}(T)}{C_{S}(0)^{1-n}}
\end{gathered}
$$

where:

- $C_{S}(t, T)$ - the content of the stabilizer in powder, as a function of time and temperature, mass $\%$;

- $\quad C_{s}(0)$ - initial stabilizer content, mass \%;

- $k^{\prime}(T)$ - reaction rate constants of the nth order of stabilizer consumption, at temperature $T, 1 /$ day;

- $n$ - the order of reaction.

The temperature dependence of the constant of the reaction rate of the stabilizer consumption is given by Arrhenius expression (4).

$$
k(T)=Z \exp \left(-\frac{E a}{R T}\right)
$$

where:

- Z - preexponential factor; $1 /$ day;

- $E a$ - activation energy of stabilizer consumption reaction, $\mathrm{J} / \mathrm{mol}$;

- $R$ - universal gas constant; $R=8,314 \mathrm{~J} / \mathrm{mol} \cdot \mathrm{K}$;

- $\mathrm{T}$ - temperature, $\mathrm{K}$.

The extrapolation of the calculated constant of the reaction of the stabilizer consumption from the temperatures of accelerated aging to the storage temperature is carried out using the Arrhenius expression. For different kinetic expressions (the zero, the first and $\mathrm{n}$ th order) the temperature dependence of the constant of the reaction rate of the stabilizer consumption is given by Arrhenius expression:

The lifetime of GP is the period during which the GP can be safely stored without risk for shelf ignition. Lifetime of GP $\left(\mathrm{ty}_{\mathrm{S}}\right)$ is calculated as the time required for consumption of a certain value of the stabilizer content, $\mathrm{Y}_{\mathrm{S}}$, at the storage temperature:

$$
t y_{s}=\frac{1-\left(Y_{s}\right)^{1-n}}{k(1-n)}
$$

Experimental results of remained stabilizer measuring in naturally aged GP can be described using expression for rate of reaction of the first order (exponential kinetic model) [1$3,5,9,10]$.

$$
C_{S}(t, T)=C_{S}(0) \exp \left[-k_{1}(T) t\right]
$$


where:

- $C_{S}(t, T)$ - the content of the stabilizer in powder, depending on the time, mass \%;

- $C_{S}(0)$ - the initial content of the stabilizer, mass $\%$;

- $k_{1}(T)$ - reaction rate constants of the first order of stabilizer consumption, at temperature $T, 1 /$ day;

- $t$ - time of ageing, day.

Constant of the reaction rate of the stabilizer consumption at temperature $T, k_{1}(T)$ is calculated according to expression

$$
k_{1}(T)=\frac{1}{t} \ln \frac{C_{S}(t, T)}{C_{S}(0)}
$$

For first order reaction, $\ln \frac{C_{S}(t, T)}{C_{S}(0)}=f(t)$ is linear and value of $k_{1}(T)$ can be obtained as slope of line.

Lifetime of GP, $t y_{\mathrm{s}}$ is calculated as the time required for consumption of the determined value of the stabilizer content $Y_{S}$, at the storage temperature

$$
\begin{gathered}
Y_{S}=\frac{C_{S}(t, T)}{C_{S}(0)} \\
t y_{S}=\frac{1}{k_{1}(T)} \ln \left(\frac{1}{Y_{s}}\right)
\end{gathered}
$$

There are different procedures of temperature parameterization of the reaction rate constant of stabilizer consumption, but in this article, focus is on the application of Arrhenius and Van't Hoff expressions [11].

According Arrhenius expression (4), relation between time-temperature loads at two conditions $\left(t_{1}, T_{1}\right)$ and $\left(t_{2}, T_{2}\right)$ with one value of activation energy at all temperature interval from $T_{1}$ to $T_{2}$ is given $[8,11]$.

$$
\frac{k_{2}\left(T_{2}\right)}{k_{1}\left(T_{1}\right)}=\exp \left(-\frac{E a}{R} \cdot\left(\frac{1}{T_{2}}-\frac{1}{T_{1}}\right)\right)=\frac{t_{1}\left(T_{1}\right)}{t_{2}\left(T_{2}\right)}
$$

where:

- $k_{1}\left(T_{1}\right)$ - constant of stabilizer consumption rate at the storage temperature $T_{1} .1 /$ day;

- $k_{2}\left(T_{2}\right)$ - constant of stabilizer consumption rate at the measurement temperature $\mathrm{T}_{2,}, 1$ day;

- $t_{1}\left(T_{1}\right)$ - time required for consumption of a certain stabilizer content at storage temperature $\mathrm{T}_{1}$, year;

- $t_{2}\left(T_{2}\right)$ - time required for the consumption of a certain content stabilizer at the measurement temperature $\mathrm{T}_{2}$, days;

- $T_{1}$ - storage temperature, ${ }^{\circ} \mathrm{C}$;

- $T_{2}$ - measurement temperature, ${ }^{\circ} \mathrm{C}$.

Standard AOP-48 Ed.2 and standard STANAG 4582 are using the same extrapolation procedure. For extrapolation data of stabilizer consumption in temperature interval under the $60^{\circ} \mathrm{C}$, empiric activation energy $E a=80 \mathrm{~kJ} / \mathrm{mol}$ should be used and for extrapolation in temperature interval above $60^{\circ} \mathrm{C}$, emp iric activation energy $E a=120 \mathrm{~kJ} / \mathrm{mol}$ should be used $[6,7]$.

Van't Hoff expression can be used for the temperature parameterization of the reaction rate constant of stabilizer consumption, too $[3,8,10,11]$.

$$
\frac{k_{2}\left(T_{2}\right)}{k_{1}\left(T_{1}\right)}=F^{\left(\left(\frac{T_{2}-T_{1}}{\Delta T_{F}}\right)\right)}=\frac{t_{1}\left(T_{1}\right)}{t_{2}\left(T_{2}\right)}
$$

where:

- $F$ - factor of change of reaction rate of stabilizer consumption for temperature change $10^{\circ} \mathrm{C}$;
- $t_{1}\left(T_{1}\right)$ - time required for consumption of a certain stabilizer content at storage temperature $T_{1}$, year;

- $\mathrm{t}_{2}\left(T_{2}\right)$ - time required for the consumption of a certain content stabilizer at the measurement temperature $T_{2}$, days;

- $k_{1}\left(T_{1}\right)$ - constant of stabilizer consumption rate at the storage temperature $T_{1}, 1 /$ day;

- $k_{2}\left(\mathrm{~T}_{2}\right)$ - constant of stabilizer consumption rate at the measurement temperature $T_{2}, 1$ day.

Factor of change of reaction rate of stabilizer consumption $(F)$ is the ratio of the constant of reaction rate of the stabilizer consumption during aging of the powder at two temperatures, which differ by $10^{\circ} \mathrm{C}$. Factor $F$ is bound to the chemical nature of matter and therefore has a constant value, regardless of the composition of GP and their behaviour in aging.

$$
t_{1}\left(T_{1}\right)=\frac{t_{2}\left(T_{2}\right)}{365,25} F^{\frac{\left(T_{2}-T_{1}\right)}{\Delta T_{F}}}
$$

- $t_{1}$ - time required for consumption of a certain stabilizer content at storage temperature, year;

- $t_{2}$ - time required for the consumption of a certain content stabilizer at the measurement temperature, days;

- $T_{2}$ - measurement temperature, ${ }^{\circ} \mathrm{C}$;

- $T_{1}$ - storage temperature, ${ }^{\circ} \mathrm{C}$;

- $\Delta T_{F}$ - temperature range for the factor value $F$ used. For this application, $\Delta T_{F}=10^{\circ} \mathrm{C}$ is used.

\section{Experimental part}

The samples of NC-40 MBL 9226 powders were artificially aged in heating tubes within thermal-blocks at $65^{\circ} \mathrm{C}, 70^{\circ} \mathrm{C}, 80^{\circ} \mathrm{C}$ and $90^{\circ} \mathrm{C}[2,3]$. In Fig. 1 thermal block with $\mathrm{NC}-40$ samples, is presented.

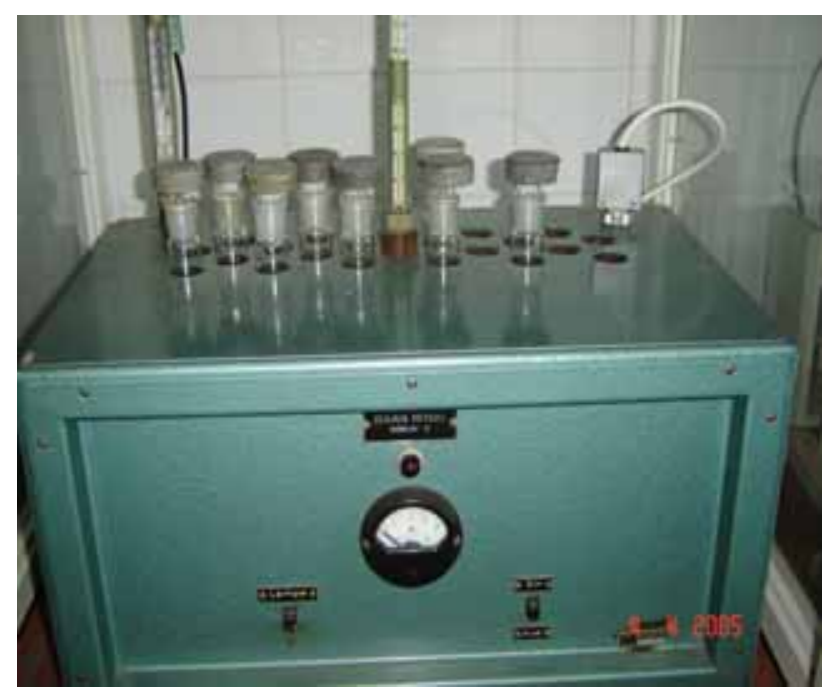

Figure 1. Artificially ageing of NC-40 MBL 9226

Experimental results of diphenylamine (DPA) consumption in NC-40 MBL 9226 single base GP during multi temperature heating, according to AOP-48 Ed. 2 were used in this article $[2,3]$. The values of the content of diphenylamine in the tested NC-40 samples were determined by procedures which are described in literature [2,3]. Liquid chromatograph "Waters 1525 EF Binary HPLC Pump" with a thermostat for column heating, the manual injector "Rheodine Model 7125", and the photodiode array detector "Waters 2998 PDA" were used for these experiments, Fig.2. Liquid chromatograph "LDC/ Milton Roy 3000" in laboratory in TRZ Kragujevac was used for these experiments, too. 


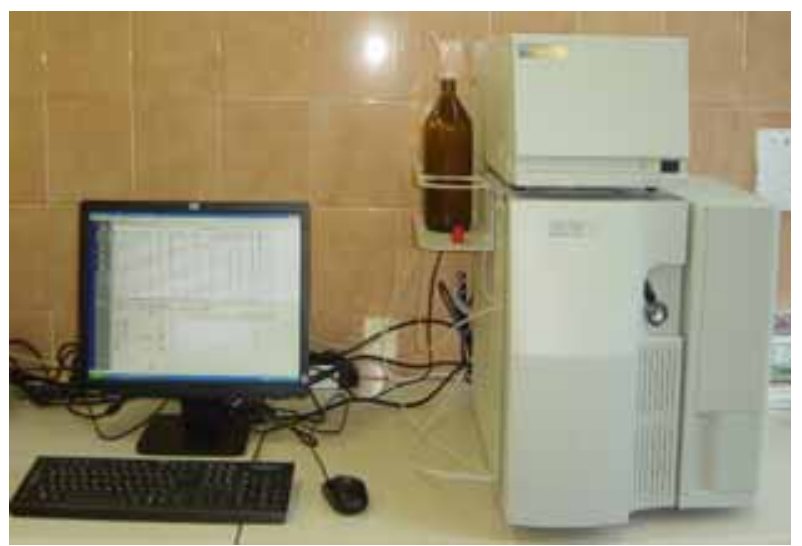

Figure 2. Liquid chromatograph

Experimental results of diphenylamine consumption in accelerated aged $\mathrm{NC}-40(\mathrm{MBL} 9226)$ powder at $90^{\circ} \mathrm{C}, 80^{\circ} \mathrm{C}$, $70^{\circ} \mathrm{C}$ and $65^{\circ} \mathrm{C}$ were mathematicaly described by kinetic model of $n^{\text {th }}$ order.

Examination is based on the available results of periodical HPLC measuring of the contents of the stabilizer remained in naturally aged samples of the single-base NC-40 gunpowder from KB-1 collection (three series: MBL 8511, MBL 9024 and MBL 8922) [2,3].

The samples were storaged in the warehouse type M-40 in conditions of continental climate with average annual storage temperature, $15^{\circ} \mathrm{C}[2-4,5]$. The results were obtained during periodical controls of chemical stability of powders from KB1 collection in laboratory in TRZ Kragujevac.

A first order reaction is assumed for stabilizer consumption in naturally aged powder and results of three series of NC-40 (MBL 8511, MBL 9024 and MBL 8922) from KB-1 at average annual temperature of storage $15^{\circ} \mathrm{C}$, were mathematicaly described by exponential kinetic model.

Temperature parameterization of constant of the rate of the stabilizer consumption from storage temperature $15^{\circ} \mathrm{C}$ to ambient $25^{\circ} \mathrm{C}$ and higher temperature was carried out using the Arrhenius expression (10). The values of lifetime of naturally aged NC-40: series MBL 8511, MBL 9024 and MBL 8922 and artificially aged NC-40 serie MBL 9226 were calculated.

\section{Results and discussion}

The results of the HPLC analysis of the powder samples subjected to accelerated ageing were described by the kinetic model of $n^{\text {th }}$ order and presented in Figures 3-6. The lines in these figures represent the curves, fitted by the method of least squares in accordance with expression (2) for the reaction of $n^{\text {th }}$ order to experimental data.

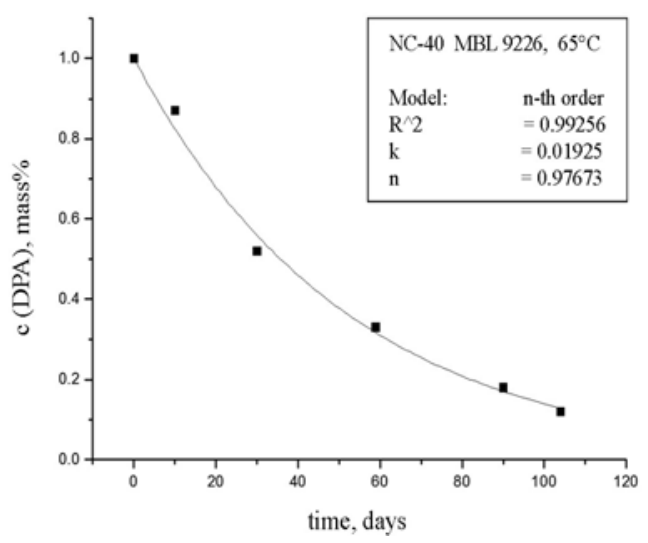

Figure 3. DPA consumption in NC-40 MBL 9226 - description by $n^{\text {th }}$ order reaction at $65^{\circ} \mathrm{C}$

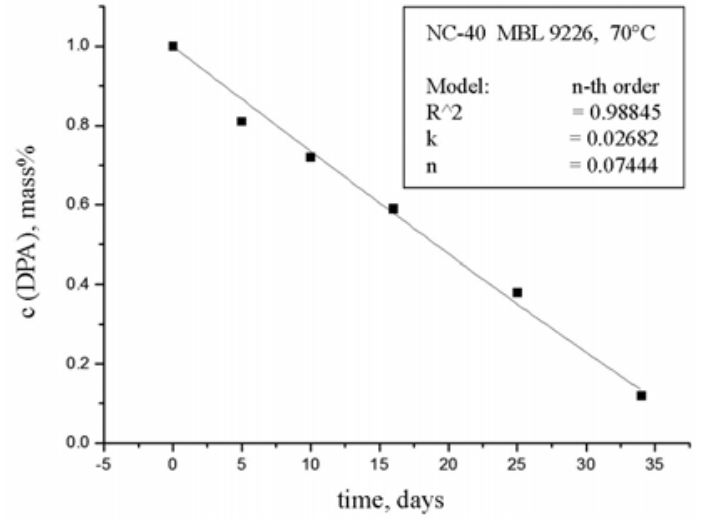

Figure 4. DPA consumption in NC-40 MBL 9226 - description by $n^{\text {th }}$ order reaction at $70^{\circ} \mathrm{C}$

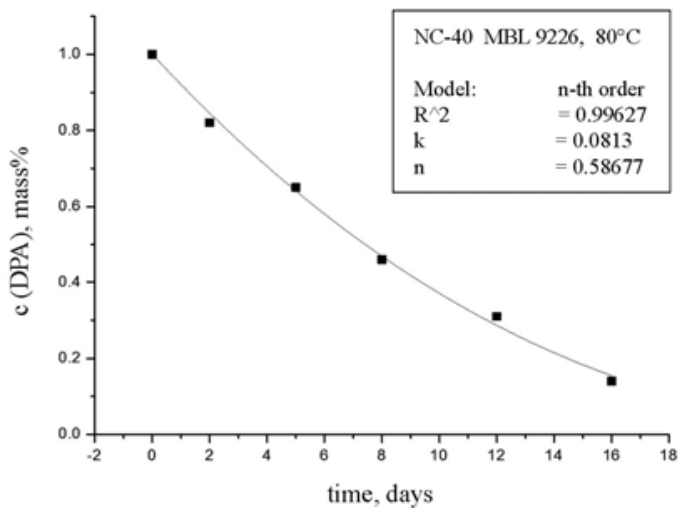

Figure 5. DPA consumption in NC-40 MBL 9226 - description by $n^{\text {th }}$ order reaction at $80^{\circ} \mathrm{C}$

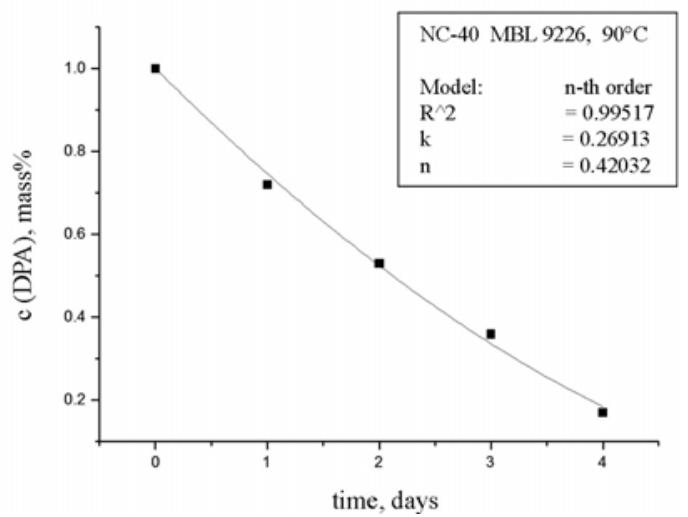

Figure 6. DPA consumption in NC-40 MBL 9226 - description by $n^{\text {th }}$ order reaction at $90^{\circ} \mathrm{C}$

The Arrhenius plots of the reaction rate constants of the consumption of DPA are presented in Fig.7 for the powder NC-40 MBL 9226.

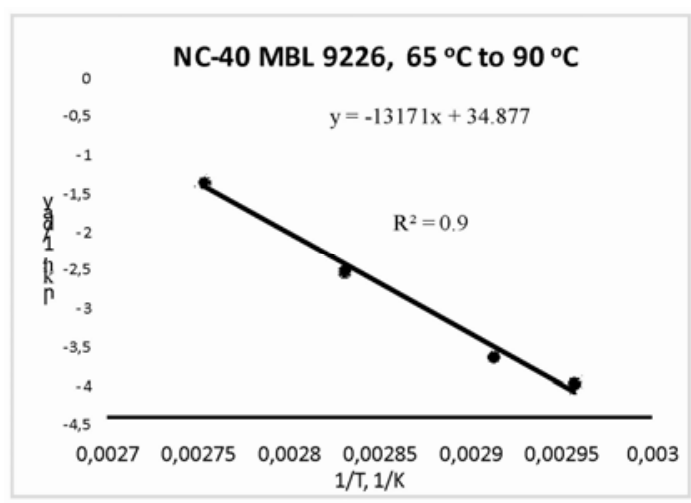

Figure 7. Arhenius plot of the reaction rate constants of the DPA consumption in the NC-40 MBL 9226 from $65^{\circ} \mathrm{C}$ to $90^{\circ} \mathrm{C}$ - kinetic model of $n^{\text {th }}$ order 
The reaction rate constants of the consumption of DPA at various temperatures and the kinetic parameters of the model of $\mathrm{n}^{\text {th }}$ order are showed in Table 1 . The reaction rate constants were calculated at a storage temperature of $25^{\circ} \mathrm{C}$, too (Table 1). Value of activation energy, $109,5 \mathrm{~kJ} / \mathrm{mol}$ for $\mathrm{NC}-40 \mathrm{MBL}$ 9226 powder at temperature interval from $65^{\circ} \mathrm{C}$ to $90^{\circ} \mathrm{C}$, was calculated according Arhenius plot and expression (4).

Table 1. Kinetic parameters and life time of NC-40 MBL 9226 - model of $n^{\text {th }}$ order according AOP-48 Ed. 2

\begin{tabular}{||c||c||}
\hline \multicolumn{2}{|c||}{$\mathrm{NC}-40$ MBL 9226} \\
\hline \hline$k_{n}$ at $65^{\circ} \mathrm{C}, 1 /$ day & 0,01925 \\
\hline$k_{n}$ at $70{ }^{\circ} \mathrm{C}, 1 /$ day & 0,02682 \\
\hline$k_{n}$ at $80^{\circ} \mathrm{C}, 1 /$ day & 0,08130 \\
\hline$k_{n}$ at $90^{\circ} \mathrm{C}, 1 /$ day & 0,26913 \\
\hline$E a, \mathrm{~kJ} / \mathrm{mol}$ & 109,5 \\
\hline $\ln \mathrm{Z}, 1 /$ day & 34,89 \\
\hline$k_{n}$ at $25^{\circ} \mathrm{C}, 1 /$ day & $9,33 \mathrm{E}-05$ \\
\hline $\begin{array}{c}n_{\text {average }} \\
\left(65^{\circ} \mathrm{C} \text { to } 90^{\circ} \mathrm{C}\right)\end{array}$ & 0,51 \\
\hline
\end{tabular}

In Table 2, the results are given of periodical HPLC measuring of stabilizer contents for series MBL 8511, MBL 9024 and MBL 8922 of naturally aged single base NC-40 powder from KB-1 collections in the conditions of continental climate.

Table 2. DPA contents and lifetime prediction of different series of NC-40 powder naturally agedat storage temperature TKB-1 $=15^{\circ} \mathrm{C}$

\begin{tabular}{|c|c|c|c|c|c|c|c|c|}
\hline \multirow{3}{*}{$\begin{array}{c}\text { Series of } \\
\text { GP, } \\
\text { MBL }\end{array}$} & \multirow{3}{*}{\begin{tabular}{|c} 
Time of \\
storage, \\
years
\end{tabular}} & \multirow{3}{*}{$\begin{array}{l}\mathrm{DPA}_{0}, \\
\text { mass } \%\end{array}$} & \multirow{3}{*}{$\begin{array}{c}\text { DPA, } \\
\text { mass } \%\end{array}$} & \multirow{3}{*}{$\begin{array}{c}\mathrm{k}_{\left(15^{\circ} \mathrm{C}\right)} \\
1 / \text { day }\end{array}$} & \multirow{2}{*}{\multicolumn{4}{|c|}{$\frac{\text { Lifetime, years }}{\mathrm{Y}_{\mathrm{DPA}}}$}} \\
\hline & & & & & & & & \\
\hline & & & & & 0,7 & 0,5 & 0,3 & 0,2 \\
\hline \multirow{5}{*}{8511} & 15 & 1,50 & 1,08 & \multirow{5}{*}{0,019} & \multirow{5}{*}{18,8} & \multirow{5}{*}{36,5} & \multirow{5}{*}{63,4} & \multirow{5}{*}{84,7} \\
\hline & 21 & 1,50 & 1,06 & & & & & \\
\hline & 22 & 1,50 & 0,99 & & & & & \\
\hline & 23 & 1,50 & 0,90 & & & & & \\
\hline & 25 & 1,50 & 0,98 & & & & & \\
\hline \multirow{4}{*}{9024} & 14 & 1,59 & 1,18 & \multirow{4}{*}{0,0238} & \multirow{4}{*}{15,0} & \multirow{4}{*}{29,1} & \multirow{4}{*}{50,5} & \multirow{4}{*}{67,6} \\
\hline & 16 & 1,59 & 1,16 & & & & & \\
\hline & 17 & 1,59 & 1,06 & & & & & \\
\hline & 18 & 1,59 & 0,97 & & & & & \\
\hline \multirow{3}{*}{8922} & 17 & 1,40 & 1,03 & \multirow{3}{*}{0,0165} & \multirow{3}{*}{21,6} & \multirow{3}{*}{42,0} & \multirow{3}{*}{72,9} & \multirow{3}{*}{97,5} \\
\hline & 18 & 1,40 & 1,02 & & & & & \\
\hline & 21 & 1,40 & 1,03 & & & & & \\
\hline
\end{tabular}

Results were mathematically described by the exponential expression for the reaction rate of the first order (6) and reaction rate constants of the consumption of stabilizer $D P A$, $k\left(15^{\circ} \mathrm{C}\right)$ at $T_{K B-1}=15^{\circ} \mathrm{C}$ were obtained as a slope of line (7) and displayed in Table 2.

Table 2 also shows the values of the lifetime prediction calculated according expression (9) of naturally aged powder at $T_{K B-1}=15^{\circ} \mathrm{C}$, at different degrees of degradation of the stabilizer, $Y_{D P A}(8)$.

It is important to note that the predicted lifetime of naturally aged powders which were calculated at the average annual storage temperature, $15^{\circ} \mathrm{C}$, would only be achieved in the absence of deviations from the prescribed technological parameters during the production process of GP and in the absence of deviations during the storage of GP in optimal conditions. However, in reality, this is impossible to achieve.

Since some ammunition during many years of storage has been removed from the warehouse several times and has been operating under unfavourable conditions for a certain period of the time, it is necessary to estimate the average storage temperature, which is about $20^{\circ} \mathrm{C}$. To additionally include other factors (conditions of the storage, change in the mechanism of consumption of the stabilizer, humidity, etc.) that influence the chemical stability of powders under natural storage conditions, in order to reliably predict of service lifetime, it is necessary to take into account the ambient temperature of $25^{\circ} \mathrm{C}$, as prescribed by standard AOP-48 Ed. 2 [6].

Therefore, it is necessary to extrapolate the obtained results from the conditions of natural aging of powders in $K B-1$ at $15^{\circ} \mathrm{C}$ to ambient temperature $25^{\circ} \mathrm{C}$, Table 3 .

Table 3. Extrapolation of reaction rate constants of $D P A$ consumption in naturally aged powder $\mathrm{NC}-40$ from $15^{\circ} \mathrm{C}$ to $25^{\circ} \mathrm{C}$

\begin{tabular}{|c|c|c|c|}
\hline \multirow{3}{*}{ Extrapolation procedure } & \multicolumn{3}{|c|}{ Series of powder NC-40 } \\
\hline & 8511 & 9024 & 8922 \\
\hline & \multicolumn{3}{|c|}{$k$ at $25^{\circ} \mathrm{C}, 1 /$ day } \\
\hline$E a=80 \mathrm{~kJ} / \mathrm{mol}$ & 0,0582 & 0,0729 & 0,0505 \\
\hline$E a=120 \mathrm{~kJ} / \mathrm{mol}$ & 0,1019 & 0,1277 & 0,0885 \\
\hline$E a=109,5 \mathrm{~kJ} / \mathrm{mol}$ & 0,0880 & 0,1102 & 0,0764 \\
\hline$F=3$ & 0,0570 & 0,0714 & 0,0495 \\
\hline
\end{tabular}

The temperature parameterization of stabilizer consumption in naturally aged powder NC-40 (series MBL 8511, MBL 9024, MBL 8922) was carried out using the Arrhenius expression (10). The empirical values of the activation energy was $80 \mathrm{~kJ} / \mathrm{mol}$ or $120 \mathrm{~kJ} / \mathrm{mol}$ and value of activation energy was $E a=109,5 \mathrm{~kJ} / \mathrm{mol}$, which was experimentally determined for the same type of NC-40 MBL 9226 powder by AOP-48 Ed.2.

The temperature parameterization of stabilizer consumption in naturally aged powder NC-40 (series MBL 8511, MBL 9024, MBL 8922) was carried out using the Van't Hoff expression, too (11).

The Table 4 shows the results of the lifetime prediction (9) of three series of naturally aged powder $\mathrm{NC}-40$ at $25^{\circ} \mathrm{C}$ at different degrees of degradation of the stabilizer, $Y_{D P A}(8)$.

The results of lifetime prediction of accelerated aged powder NC-40 series 9226 according standard AOP-48 Ed.2 are presented in Table 4, too. In order to compare the results of the lifetime prediction of naturally and artificially aged NC-40 powder, experimental value of $E a=109,5 \mathrm{~kJ} / \mathrm{mol}$ was obtained using the $n^{\text {th }}$ order kinetic model to describe the consumption of the stabilizer in the accelerated aged powder $\mathrm{NC}-40 \mathrm{MBL} 9226$ at temperatures $65^{\circ} \mathrm{C}, 70^{\circ} \mathrm{C}, 80^{\circ} \mathrm{C}$ and $90^{\circ} \mathrm{C}$. The life times of the GP were calculated according to the equines (5) as a storage times at $25^{\circ} \mathrm{C}$, after which a different degrees of degradation of the stabilizer, $Y_{D P A}$ were achieved (8).

Table 4. Lifetime prediction of naturally and artificially aged powders NC-40 at $25^{\circ} \mathrm{C}$

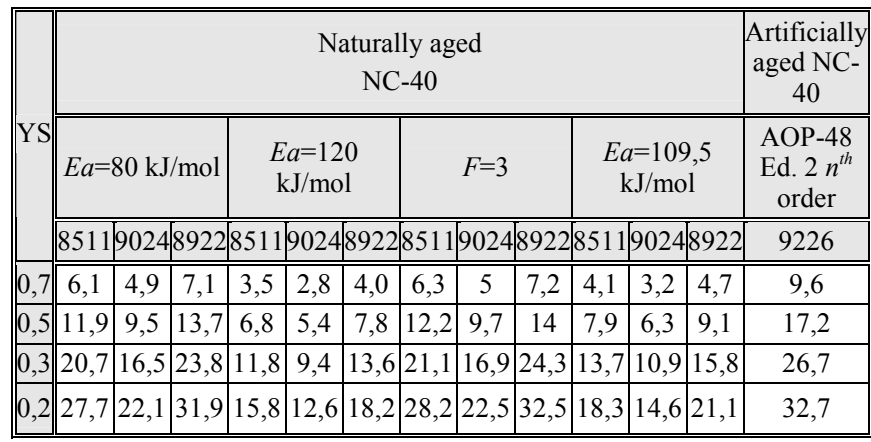

By analysing the results presented in Table 4, the best approximation of the calculated values of the lifetime of artificially and naturally aged powders were noticed when the 
empirical value of activation energy $E a=80 \mathrm{~kJ} / \mathrm{mol}$ was used for extrapolation from $15^{\circ} \mathrm{C}$ to the $25^{\circ} \mathrm{C}$.

The lifetime calculated by using the activation energy values $E a=80 \mathrm{~kJ} / \mathrm{mol}$, is also consistent with the lifetime calculated by using of the Vant Hof's extrapolation method with $F=3$.

In Table 5 the results are given of calculating of the lifetime of powderNC-40 MBL 8511 and NC-40 MBL 8922, which showed the highest agreement with the results of the accelerated aging of powder NC-40 MBL 9226.

Table 5. Comparison of the lifetime of naturally and artificially aged powder NC-40

\begin{tabular}{||c||c|c|c||}
\hline \multicolumn{4}{|c||}{ Time for consumption of $80 \%$ stabilizer at $25^{\circ} \mathrm{C}$} \\
\hline \hline \multirow{3}{*}{$\begin{array}{c}\text { NC-40 } \\
\text { series } \\
\text { MBL }\end{array}$} & $\begin{array}{c}\text { NC-40 the naturally aged the } \\
\text { first order }\end{array}$ & $\begin{array}{c}\text { NC-40 series MBL } 9226 \\
\text { artificially aged the } n^{\text {th }} \text { order }\end{array}$ \\
\cline { 2 - 4 } & Ea=80 kJ/mol & $\mathrm{F}=3$ & Ea=109,5 kJ/mol \\
\hline \hline 8511 & \multicolumn{2}{|c|}{ lifetime,years } & lifetime,years \\
\hline 8922 & 27,7 & 28,2 & 32,7 \\
\hline
\end{tabular}

Nowadays, for lifetime prediction of powders and propellants the NATO member states use the very actual standard AOP-48 Ed.2. It is based on accelerated aging of powder and description of stabilizer consumption with a kinetic expression of $n^{\text {th }}$ order. It is worldwide used standard which presents great progress in the area of chemical stability and lifetime prediction of GP.

Time for $\%$ stabilizer consumption at $25^{\circ} \mathrm{C}$ was determined and the results were:

- lifetime of accelerated aged powder NC-40 MBL 9226, calculated according to standard AOP-48 Ed. 2 is 32,5 years.

- lifetime of NC-40 MBL 8922 calculated by activation energy values $E a=80 \mathrm{~kJ} / \mathrm{mol}$ is 31,9 years,

- lifetime of NC-40 MBL 8511 calculated by activation energy values $E a=80 \mathrm{~kJ} / \mathrm{mol}$ is 27,7 years.

It can be seen that the results of lifetime prediction of naturally aged powder NC-40 MBL 8511 and NC-40 MBL 8922 are in accordance whit the results of the accelerated aging of powder NC-40 MBL 9226. The use of empirical activation energy of $80 \mathrm{~kJ} / \mathrm{mol}$ is reliable for use in this case, because it contains a certain safety factor, which takes into account all parameters that, in the conditions of natural aging, significantly affect chemical stability, such as storage conditions and changes in stabilizer consumption mechanism. This conclusion is consistent with the current STANAG 4582 extrapolation process. Mentioned extrapolation procedure or temperatures below $60^{\circ} \mathrm{C}$, prescribes the application of the empirical value $E a=80 \mathrm{~kJ} / \mathrm{mol}[6,7]$.

From the ratio of the reaction rate constants of the stabilizer consumption in powder NC- 40 MBL 8922, $F=k\left(25^{\circ} \mathrm{C}\right) / k\left(15^{\circ} \mathrm{C}\right)=3,06$ and Vant Hoff's rule that value of $F=3$ for difference between temperatures $10^{\circ} \mathrm{C}$, it means that at a temperature of $25^{\circ} \mathrm{C}$, are obtained 3 times less, but the most important the reliable values of the lifetime in relation to the average annual storage temperature of $15^{\circ} \mathrm{C}$, Table 6.

Table 6. Value of $F$ for naturally aged NC-40

\begin{tabular}{||c|c|c|c||}
\hline $\begin{array}{c}\text { Naturally aged } \\
\text { NC-40 }\end{array}$ & $\begin{array}{c}k\left(15^{\circ} \mathrm{C}\right) \\
1 / \text { day }\end{array}$ & $\begin{array}{c}k\left(25^{\circ} \mathrm{C}\right) \\
E a=80 \mathrm{~kJ} / \mathrm{mol} \\
1 / \text { day }\end{array}$ & $\begin{array}{c}F=k\left(25^{\circ} \mathrm{C}\right) / \mathrm{k}\left(15^{\circ} \mathrm{C}\right) \\
\Delta T_{F}=10^{\circ} \mathrm{C}\end{array}$ \\
\hline \hline MBL 8511 & 0,019 & 0,0582 & 3,06 \\
\hline MBL 8922 & 0,0165 & 0,0505 & 3,06 \\
\hline
\end{tabular}

For consumption of $80 \%$ stabiliser, lifetime values were calculated:

- lifetime of NC-40 series MBL 8922, calculated at storage temperature, $15^{\circ} \mathrm{C}$, is 97,5 years.

- lifetime calculated at $25^{\circ} \mathrm{C}$ by using of Vant Hoff's extrapolation method with $F=3$ for MBL 8922 is 32,5 years and for MBL 8511 is 28,2 years.

Fig.8 presents the graphical results of the lifetime calculation of naturally aged NC-40 MBL 8922 powder, at $Y_{D F A}=0,7$ by various procedures of extrapolation at a temperatures ranging from $15^{\circ} \mathrm{C}$ to $105^{\circ} \mathrm{C}$.

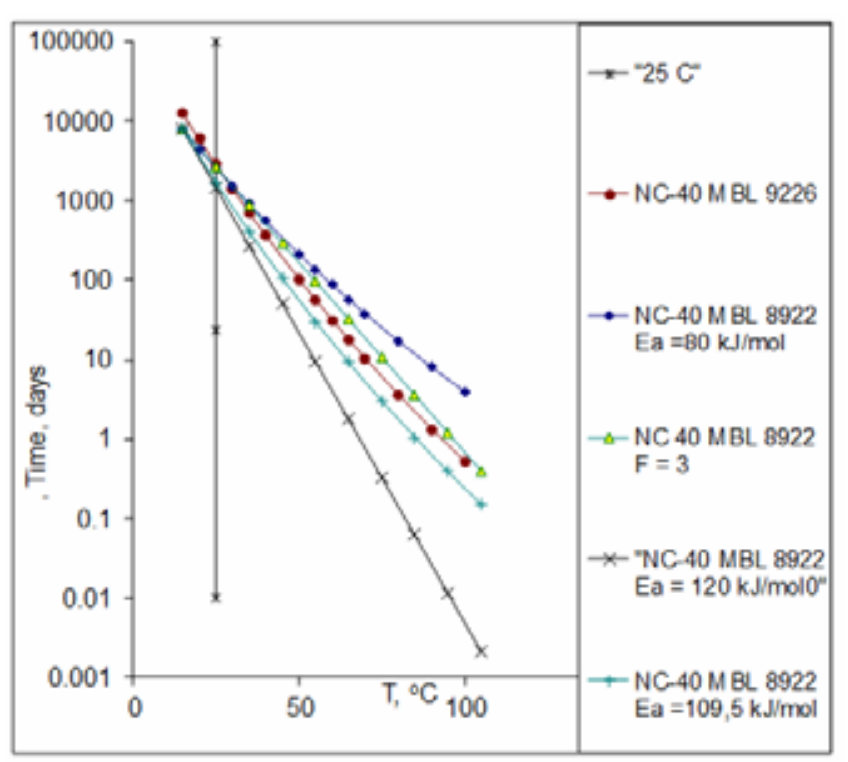

Figure 8. An extrapolation procedures of NC-40 powder from T-t conditions of natural and accelerated aging, to an ambient temperature of $25^{\circ} \mathrm{C}$.

By analyzing of the Fig. 8 in the temperature range of $25^{\circ} \mathrm{C}$ to $30^{\circ} \mathrm{C}$, excellent matching of the

- accelerated aging powder NC-40 MBL 9226 (AOP-48 Ed.2);

- naturally aged powder NC-40 MBL 8922 (empirical $E a=$ $80 \mathrm{~kJ} / \mathrm{mol}$ ) and

- naturally aged powder NC-40 MBL 8922 (with $F=3$ ), exists.

\section{Conclusion}

A comparative analysis of the results of the lifetime prediction of naturally and artificially aged different series of $\mathrm{NC}-40$ gunpowder at ambient temperature $25^{\circ} \mathrm{C}$, was carried out.

Available results of periodical HPLC measuring of the stabilizer content accordingto standard SORS 8069/91 in natural aged NC-40 gunpowder (series: MBL 8511, MBL 9024 and MBL 8922) from KB-1 collection in conditions of continental climate at average annual temperature of storage $15^{\circ} \mathrm{C}$,were used. The mentioned results were mathematical described by exponential kinetic model. Temperature parameterization of the stabilizer consumption in naturally aged single base gunpowderfrom storage temperature $15^{\circ} \mathrm{C}$ to ambient temperature of $25^{\circ} \mathrm{C}$ was carried out.

Lifetime of naturally aged different series of GPs at ambient temperature $25^{\circ} \mathrm{C}$ was calculated. Experimental results of HPLC measuring of DPA content in NC-40 MBL 9226, which is artificially aged in heating tubes within thermal-blocks at $65^{\circ} \mathrm{C}, 70{ }^{\circ} \mathrm{C}, 80{ }^{\circ} \mathrm{C}$ and $90^{\circ} \mathrm{C}$, were mathematical described by kinetic model of $\mathrm{n}^{\text {th }}$ order 
according standard AOP-48 Ed.2. Lifetime of artificially aged $\mathrm{NC}-409226$ powder at ambient temperature $25^{\circ} \mathrm{C}$ was calculated.

A comparative analysis of the results of the lifetime prediction of naturally and artificially aged different series of NC-40 powder at ambient temperature $25^{\circ} \mathrm{C}$ has shown that: - empirical value of activation energy of $80 \mathrm{~kJ} / \mathrm{mol}$ can be used for extrapolation of the reaction rate constant of the stabilizer consumption in the naturally aged GP from average annual temperature $15^{\circ} \mathrm{C}$ in $\mathrm{KB}-1$ collection (conditions of continental climate) to an ambient temperature of $25^{\circ} \mathrm{C}$.

- the lifetime of naturally aged GPs calculate at the described way is in accordance with the lifetime of artificially aged GPS at ambient temperature $25^{\circ} \mathrm{C}$ calculated according to AOP-48 Ed. 2.

- the lifetime of the naturally aged GPS calculate at the described way is in accordance with the lifetime which was calculated by Vant Hof extrapolation method.

The use of empirical activation energy of $80 \mathrm{~kJ} / \mathrm{mol}$ is reliable for use in this case, because it contains a certain safety factor, which takes into account all parameters that, in the conditions of natural aging, significantly affect chemical stability, such as storage conditions and changes in stabilizer consumption mechanism. This conclusion is consistent with the current STANAG 4582 extrapolation procedure, which are for temperatures below $60^{\circ} \mathrm{C}$, prescribes the application of the empirical value $E a=80 \mathrm{~kJ} / \mathrm{mol}$.

\section{Acknowledgement}

Authors are grateful to the Ministry of Defence and the Ministry of Education, Science and Technological Development of the Republic of Serbia for the support of this research (Project TR 34028, 2010-2018).

\section{Literature}

[1] SORS 8069/91: Praćenje hemijske stabilnosti baruta i raketnih goriva, Beograd, SRBIJA, 1991.

[2] GRBOVIĆ.L.: Istraživanje hemjske stabilnosti malodimnih baruta,
Doktorska disertacija, Vojnotehnička akademija, Beograd, SRBIJA, 2006.

[3] JELISAVAC,Lj.: Unapređenje sistema kontrole hemijske stabilnosti baruta $i$ raketnih goriva, Doktorska disertacija, Vojna akademija, Beograd, SRBIJA, 2013.

[4] Zbornik radova, Kvalitet uskladištenih UbS, Tematski skup, TU GŠ VJ, Beograd, SRBIJA, 1994.

[5] GRBOVIĆ,L., STOJILJKOVIĆ,S.: Korelacija rezultata ispitivanja hemijske stabilnosti prirodno i ubrzano starenih baruta, Vojnotehnički glasnik, ISSN 0042-8469, 2005, No.5, str.442-450.

[6] AOP-48 Ed.2: Explosives, nitrocellulose based propellants - stability test procedures and requirements using stabilizer depletion, Brussels: North Atlantic Treaty Organization, Military Agency for Standardization, 2008.

[7] STANAG 4582: Explosives, nitrocellulose based propellants - stability test procedures and requirements usingHFCBrussels: North Atlantic Treaty Organization, Military Agency for Standardization, 2004.

[8] BOHN,M.A.: NC-Based Energetic Materials Stability, Decomposition And Ageing, Presentation on the meeting Nitrocellulose supply, Ageing and Characterization, Aldermaston, ENGLAND, 2007.

[9] JELISAVAC,Lj.: Life-Time Predicion of Double-Base-Propellants in accordance with Serbian and NATO Standards, ScientificTechnical Review, ISSN 1820-0206, 2010, Vol.60, No.1, pp.12-18.

[10] JELISAVAC,Lj.: Hemijska stabilnost i vek upotrebe baruta i raketnih goriva, Kumulativna naučno-tehnička informacija, VTI, Beograd, SRBIJA, ISSN 1820-3418, ISBN 978-86-81123-31-7, 2009, Vol.XLIII, No.2.

[11] BOHN,M.A.: Prediction of equivalent time-temperature loads for accelerated ageing to simulate preset in-storage ageing and timetemperature profil loads, $40^{\text {th }}$ Intern. Annual Conference of ICT , Karlsruhe, GERMANY, 2009, Proceedings, pp.78-1 to 78-28.

[12] MALLINSON,LG., BOHN,M.A.: Modelling of StabilizerReactions in Gun and Rocket Propellants, Ageing Studies and Lifetime Extension of Materials, Proceedings of an international conference on Ageing Studies and Lifetime Extension of Materials, Springer, 2001, pp.449466.

[13] VOGELSANGER,B.: Results of the multi-national study about STANAG 4620/AOP-48 Ed,2 (new NATO standard for assessment of chemical stability and safe storage life of propellants using stabiliser depletion), Internat. Annual Conference-Fraunhofer Institut, 2006.

\title{
Temperaturna parametrizacija potrošnje stabilizatora u prirodno i veštački starenim jednobaznim barutima
}

\begin{abstract}
Najrealniji način ocene hemijske stabilnosti i predviđanja veka bezbednog skladištenja nitroceluloznih (NC) baruta merenjem sadržaja stabilizatora je praćenje potrošnje stabilizatora sa vremenom, u uslovima skladištenja. Zahvaljujući ograničenom vremenu raspoloživom za ispitivanja, u cilju realnijeg predviđanja veka bezbednog skladištenja baruta, razvijene su različite metode zasnovane na veštačkom starenju, čime se simulira prirodno starenje baruta. Cilj je postizanje ekvivalentnog starenja u mnogo kraćem vremenskom periodu, nego na temperaturi okoline u uslovima prirodnog skladištenja. U radu su opisani rezultati uporedne analize predviđanja veka bezbednog skladištenja prirodno i veštački starenih različitih serija NC-40 baruta na temperaturi okoline $25^{\circ} \mathrm{C}$.

Pokazano je da empirijska vrednost energije aktivacije, $80 \mathrm{~kJ} / \mathrm{mol}$, može da se koristi za ekstrapolaciju konstante brzine reakcije potrošnje stabilizatora u prirodno starenim barutima $\mathrm{NC}-40$, sa prosečne godišnje temperature u kolekciji baruta $\mathrm{KB}-1,15^{\circ} \mathrm{C}$ (uslovi kontinentalne klime) na temperaturu okoline $25^{\circ} \mathrm{C}$. Vek bezbednog skladištenja prirodno starenih baruta NC-40 izračunat na ovaj način je u saglasnosti sa vekom bezbednog skladištenja veštački starenih baruta, koji je izračunat na temperaturi okoline $25^{\circ} \mathrm{C}$, prema širom sveta korišćenom standardu AOP-48 Ed. 2. Vek bezbednog skladištenja prirodno starenih baruta NC-40 izračunat na ovaj način je takođe saglasan sa vekom bezbednog skladištenja baruta izračunatim primenom Vant Hofovog ekstrapolacionog postupka.
\end{abstract}

Kljune reči: barut, jednobazni barut, hemijska stabilnost, skladištenje, bezbednost, stabilizatori, prirodno starenje, veštačko starenje, procena veka bezbednosti. 


\title{
Paramétrage de température de la consommation des stabilisateurs chez les poudres monobasiques vieillies naturellement ou artificiellement
}

\begin{abstract}
La plus sure façon de l'évaluation de stabilité chimique et la prédiction de durée de vie pour le stockage en sécurité des poudres de nitrocellulose (PN) par le mesurage du contenu de stabilisateur est à l'aide du suivi de consommation de stabilisateur avec le temps dans les conditions de stockage. En conséquence du temps limité disponible pour les essais, dans le but de la plus réelle prédiction de la durée de stockage des poudres en sécurité, on a développé les différentes méthodes basées sur le vieillissement artificiel ce qui simule le vieillissement naturel de poudre. Le but était de réaliser le vieillissement équivalent dans une intervalle de temps beaucoup plus courte par rapport à la température ambiante dans les conditions de stockage naturel. Dans ce papier on a décrit les résultats de l'analyse comparée de la prédiction de la durée de vie de stockage en sécurité de différentes séries de poudres PN 40 vieillies naturellement ou artificiellement à la température ambiante de $25^{\circ} \mathrm{C}$. On a démontré que la valeur empirique de l'énergie d'activation $80 \mathrm{~kJ} / \mathrm{mol}$ peut s'utiliser pour l'extrapolation de la constante de vitesse de réaction de la consommation de stabilisateur chez les poudres NC vieillies naturellement de la température moyenne annuelle de $1^{\circ} \mathrm{C}$ dans la collection de poudre KB-1(conditions de climat continental) jusqu'à la température ambiante de $25^{\circ} \mathrm{C}$. La durée de stockage en sécurité des poudres $\mathrm{PN}-40$ vieillies naturellement calculée de cette façon est en accord avec la durée de stockage des poudres vieillies artificiellement calculée à la température ambiante de $25^{\circ} \mathrm{C}$ selon la norme utilisée mondialement AOP-48 Ed.2. La durée de stockage en sécurité des poudres PN-40 vieillies naturellement calculée ainsi est en accord aussi avec la durée de stockage en sécurité chez les poudres calculée par emploi du procédé d'extrapolation de Van't Hoff.
\end{abstract}

Mots clés: poudre, poudre monobasique, stabilité chimique, stockage, sécurité, stabilisateur, vieillissement naturel, vieillissement artificiel, estimation de la durée de sécurité.

\section{Температурная параметризация потребления стабилизатора в естественно и искусственно стареющих однобазковых порохах}

Самый надёжный способ оценки химической стабильности и прогнозирования срока безопасного хранения нитроцеллюлозных (НЦ) порохов путём измерения содержания стабилизатора заключается в том, чтобы контролировать потребление стабилизатора во времени в условиях хранения. В результате ограниченного времени, необходимого для тестирования, а для более точного прогнозирования срока безопасного хранения пороха были разработаны различные методы, основанные на искусственном старении, которые имитируют естественное старение порохов. Целью является достижение эквивалентного старения в гораздо более короткий период времени, чем при температуре окружающей среды в условиях естественного хранения.

В этом документе описаны результаты сравнительного анализа прогноза срока безопасного хранения естественно и искусственно стареющих различных сортов НЦ-40 порохов при температуре окружающей среды $25{ }^{\circ} \mathrm{C}$.

Здесь было показано, что значение эмпирической энергии активации 80 кДж / моль может быть использовано для экстраполяции постоянной скорости реакции расхода стабилизатора в естественно стареющих порохах НЦ-40 со средней годовой температурой в коллекции порохов КБ-1, $15^{\circ} \mathrm{C}$ (континентальные климатические условия) до температуры окружающей среды $25^{\circ} \mathrm{C}$. Продолжительность безопасного хранения естественно стареющих порохов НЦ-40 рассчитывается таким образом в соответствии со сроком безопасного хранения искуственно стареющих порохов, рассчитанных при температуре окружающей среды $25^{\circ} \mathrm{C}$, с использованием мирового стандарта АОР-48 Ed.2. Срок безопасного хранения естественно стареющих порохов НЦ-40, рассчитанный таким образом, также соответствует сроку безопасного хранения порохов, рассчитанным с использованием экстраполяции Vаnt Ноf поступка.

Ключевые слова: чёрный порох, однобазковый порох, химическая стабильность, хранение, безопасность, стабилизаторы, естественное старение, искусственное старение, оценка безопасности. 